http://jmscr.igmpublication.org/home/ ISSN (e)-2347-176x ISSN (p) 2455-0450

crossref DOI: https://dx.doi.org/10.18535/jmscr/v8i2.163

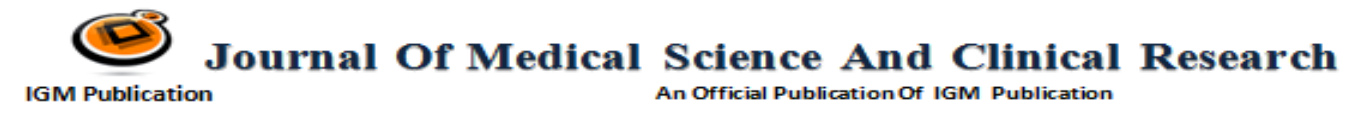

\title{
Evaluation of Brainstem Auditory Evoked Potential in Children of 1-3 Years with Receptive Language Disorder
}

Authors

\section{Dr Mandrita Chatterjee ${ }^{1 *}$, Dr Sonali Majumdar ${ }^{2}$, Dr (Prof.) Md. Shoeb Khan ${ }^{3}$}

${ }^{1}$ Junior Resident, Department of Physiology, R. G. Kar Medical College, Kolkata, West Bengal, India ${ }^{2}$ Associate Professor, Department of Physiology, R. G. Kar Medical College, Kolkata, West Bengal, India

${ }^{3}$ Professor, Department of Physiology, R. G. Kar Medical College, Kolkata, West Bengal, India *Corresponding Author

Dr Mandrita Chatterjee

\begin{abstract}
Background: Receptive Language Disorder $(R L D)$ is a condition where a child has trouble understanding and processing words. This can affect the child's ability to communicate, learn and play with others. Hearing loss is a common cause of language disorders including RLD leading to difficulties with behaviour and poor academic achievement. Early intervention with speech and language therapy improves language outcomes. Brainstem evoked response audiometry (BERA), which assess Brainstem auditory evoked potential $(B A E P)$, is a non-invasive and objective way to evaluate functional integrity of auditory pathway. It evaluates hearing in terms of the degree of hearing loss and the type of hearing loss.

Aims: The study was done to assess the Brainstem Auditory Evoked Potential in children aged 1-3 years with receptive language disorder and to assess if any hearing loss is present by finding out the auditory threshold. Methods: An observational cross-sectional study was done in a Neurophysiology labof Eastern region of India between December, 2017 to January, 2019. 60 children with receptive language disorder from Paediatric Medicine or otorhinolaryngology (ENT) Department were taken as subjects. They were further assessed by the Early Language Milestone Scale 2 and then subjected to monaural threshold BAEP test after taking proper consent and ethical clearance. Statistical analysis was done by Student t test,

Results: The prolongation of wave 'I' and wave 'V' latency along with inter peak latencies (III-V, I-V) in both ears compared to Age matched controls was significant $(P<0.05)$. The auditory threshold was higher in both ears in children with receptive language disorder. The findings of evaluation by Early Language Milestone Scale 2 corresponded to that of BAEP findings.

Conclusions: The above study suggests that there is both central and peripheral neuropathy affecting auditory pathway of the subjects having receptive language disorder.

Keywords: BERA, Speech and Language impairment, Wave ' $V$ ', Hearing threshold, Interpeak latencies.

\section{Introduction}

Speech and language development in children is a dynamic process. Speech refers to the mechanics of oral communication by articulating verbal expressions. Language encompasses the understanding, processing, and production of communication. Children, 3 years of age or younger whose speech and language disorders are untreated may exhibit diminished reading skills, behaviour problems, and impaired psychosocial adjustment. Thus, screening and identification of a
\end{abstract}


language disorder can lead to early intervention and therapy.

Word comprehension begins to increase at age 9 months, and by 13 months the child's vocabulary may be as large as 100 words. Children need to understand spoken language before they can use language to express themselves. Receptive language disorder is a form of language disorder. It is also referred to as comprehension difficulties. A child with receptive language disorder has difficulties with understanding what is said to them. The symptoms vary between children but, generally, problems with language comprehension begin before the age of three years.

It is estimated that between 3-5\% of children have a receptive or expressive language disorder. In children 7 years old and younger in the United Kingdom the median prevalence of receptive language delay/disorder ranged from $2.63 \%$ $3.59 \%^{[1]}$. In India,the prevalence of speech and language delay was found to be $27 \% .^{[2]}$ Children with receptive language disorder involving disruptions in communication development constitute a large group of patients attending the paediatric neurology clinic here, making it a focus of our present study. It is often associated with developmental disorders such as autism, cerebral palsy or Down syndrome. ${ }^{[3]}$. In many other children with receptive language disorder, no structural or metabolic abnormality can be found possibly due to gaps in literature.

A large no of cases with Receptive language disorder occurs due to hearing loss. ${ }^{[4]}$ Hearing loss can affect a child's development of speech and language skills. When a child has difficulty hearing, the areas used for communication may not develop appropriately.

Brainstem Auditory Evoked Potential (BAEP) is an effective and non-invasive means of assessing the functional status of the auditory pathway. ${ }^{[5]}$ Among the Waves of BAEP, wave I, III, V latencies and the IPLs of these waves(I-III,III-V,IV) are the significant ones used for diagnosis ${ }^{[6]}$ There is a paucity of research specifically evaluating the BAEP in children of receptive language disorder. ${ }^{[7]}$ Data is limited in Indian population; particularly in Eastern India. This creates a milieu upon which the present study was based. The research hypothesis was Brainstem Evoked Response Potential abnormalities were present in all children aged 1-3 years with receptive language disorders

This cross-sectional study evaluated BAEP wave latencies among subjects aged 1-3 years with Receptive Language Disorder in comparison with normal children and assess hearing threshold by presence or absence of Wave $\mathrm{V}$ of BAEP. The study also aimed to document whether there was Language Impairment assessed by the Early Language Milestone Scale 2 and correlate the findings with BAEP changes.

\section{Material and Methods}

This Observational, Cross-sectional study was carried out in Department of Physiology at a tertiary care teaching Hospital from December, 2017 to January, 2019.

Study Design: Observational, Cross-sectional Sampling Design: Convenient sampling

Study Area: Neuro Physiology Lab of Department. of Physiology at tertiary care teaching hospital in Eastern India

Study Period: The study was conducted for 12 months. (December, 2017 to January, 2019)

Study Population: The study population was children aged 1 to 3 years with receptive language disorder referred to us from Department. of Paediatrics or Department. of ENT.

Sample Size: By complete enumeration, Sample Size (n) was $60 .{ }^{[8]}$

\section{Inclusion Criteria}

a. Age: 1 year- 3 years

b. Either gender

c. Parents/ Guardians who have given informed written consent

d. Children with receptive language disorder (as diagnosed by otorhinolaryngology (ENT) or Paediatrics Department) 


\section{JMSCR VoI ||08||Issue ||02||Page 949-957||February}

\section{Exclusion Criteria}

a) Children suffering from suppurative ear disease like ASOM or CSOM

b) Children suffering from Upper Respiratory Tract Infection.

c) Children with any history of use of ototoxic drugs 1 year < Age $>3$ years

d) Congenital anomalies including microtia or structural anomalies of Nervous System like brain tumour

e) Children suffering from developmental disorders such as autism, cerebral palsy or Down syndrome.

f) Children too ill to perform the test.

Study Tool: BERA test was done with Neurosoft Neuro-MEP 4 machine manufactured by Neurosoft Software Production S.A., Ivanovo, Russia

\section{Data collection and interpretation}

Children aged 1 to 3 years with receptive language disorder referred from Paediatrics or otorhinolaryngology (ENT) Department were taken as study population as per inclusion and exclusion criteria. 30 apparently healthy children of same age group were taken as Controls from Well Baby Clinic of Department of Paediatrics.

Early Language Milestone Scale $2^{[9]}$ is a simple tool that can be used to assess language development in children who are younger than three years of age. The test focuses on expressive, receptive and visual language.

The 43-item scale was completed. A pass-fail method was used to score items. A child must pass all three subtests in those items that $90 \%$ of children in the population were expected to pass.

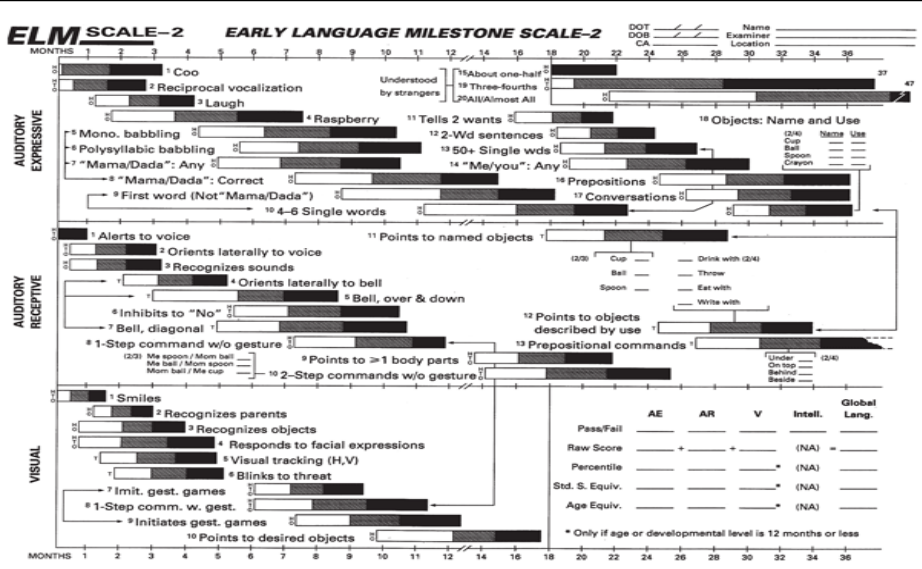

Early Language Milestone Scale 2. ${ }^{[9]}$

\section{Interpretation of the Test}

Normal/ No Language Disorder: No delays and a maximum of 1 caution

Language Disorder: two or more Cautions and /or One or more Delays

\section{Parameters Studied}

1) Age

2) Early Language Milestone Scale 2 evaluation for assessing language disorder

3) Wave Latencies (I, III, V)

4) Interpeak Latency of Waves like I-III, III-V \& I-V.

5) Grade of Hearing impairment by evaluating the wave $\mathrm{V}$ threshold after performing the ABR test at decreasing intensity measured in $\mathrm{dB}$ SPL.

\section{Procedure}

Brainstem Evoked Response Audiometry (BERA) was recorded with the help of Neurosoft NeuroMEP 4, Ivanovo, Russia. At first, parents were interviewed to fill in the study protocol ${ }^{[10]}$ and to gather a clinical history. External ear assessment was carried out and findings were documented. Parents or guardians of the children were explained about the test and asked to apply shampoo at the day before examination. They were told to come on the very day along with children and after arriving, proper consent form was being explained and signed. It was done in quiet and cool surrounding. Scalp and forehead were cleaned with Nuprep cleaning gel for electrode placement. The 
surface electrodes were used for recording Brainstem Auditory Evoked Potential. The silver cup electrodes were fixed over scalp with electrolyte paste. The electrode impedance was less than $5 \mathrm{kohm}$. The electrodes were placed at, vertex $(\mathrm{Cz})$ and at both mastoids as per International 10-20 system. The mastoids, ipsilateral and contralateral to the stimulated ear are labeled $\mathrm{Ai}$ and $\mathrm{Ac}$ respectively. The ground electrode $(\mathrm{Fz})$ were placed over forehead. Mono phasic square pulse acoustic clicks were used at 11.1 pulse/sec. Click duration was $0.1 \mathrm{~ms}$. Rarefaction clicks were used with 0.5 micro-volt sensitivity and $1 \mathrm{~ms} /$ Div sweep speed. BAEP recording was done by applying $70 \mathrm{~dB}$ stimulus intensity in ipsilateral ear and $40 \mathrm{~dB}$ lower than stimulus intensity was used as masking noise in contralateral ear. Filter setting was adjusted between $100 \mathrm{~Hz}-3000 \mathrm{~Hz}$. Two thousand evoked responses were averaged and two such recordings were taken to assess reproducibility. The absolute latencies of waves I, III, V and the I-III, III-V, I-V inter peak latency of brainstem auditory evoked potential were compared between the study group and control group to assess any significant difference of wave latencies. When BAEP parameters of cases were prolonged in respect to these normal range of values, derived from control group, or when BAEP waves are absent, both considered as abnormal.

\section{Threshold}

Thresholds are used to describe hearing sensitivity for both normal and hearing-impaired individuals. For evaluating thresholds, initially $70 \mathrm{~dB}$ was administered, then intensity was decreased and recordings were made on $50 \mathrm{~dB}$, and $30 \mathrm{~dB}$. If wave $\mathrm{V}$ was not detectable at $70 \mathrm{~dB}$ intensity then further recordings at $90 \mathrm{~dB}$ and $100 \mathrm{~dB}$ were taken. In our study, the stimulus is given as SPL and the threshold is reported in terms of nHL with $10 \mathrm{~dB}$ taken as correction factor.

According to the threshold level, the hearing impairment is graded into mild, moderate, severe and profound hearing loss. (Table 1$)^{[11]}$
Table 1 : World Health Organisation Grades of Hearing Impairment (WHO, 2008) ${ }^{[11]}$

\begin{tabular}{|c|c|c|}
\hline $\begin{array}{l}\text { Grade of } \\
\text { impairme } \\
\text { nt }\end{array}$ & $\begin{array}{l}\text { Corresponding } \\
\text { audiometric ISO } \\
\text { value }\end{array}$ & Performance \\
\hline \multicolumn{3}{|c|}{ 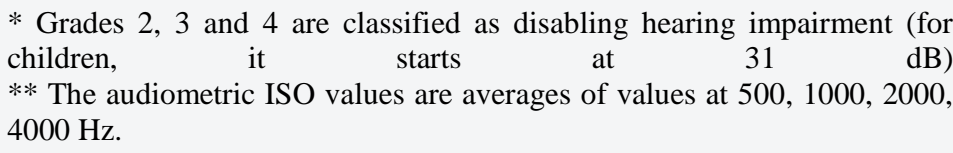 } \\
\hline $\begin{array}{l}0-\text { No } \\
\text { impairment }\end{array}$ & $\begin{array}{l}25 \mathrm{~dB} \text { or better } \\
\text { (better ear) }\end{array}$ & $\begin{array}{l}\text { No or very slight hearing } \\
\text { problems. Able to hear whispers. }\end{array}$ \\
\hline $\begin{array}{l}1-\text { Slight } \\
\text { impairment }\end{array}$ & $\begin{array}{l}26-40 \\
\text { (better ear) }\end{array}$ & $\begin{array}{l}\text { Able to hear and repeat words } \\
\text { spoken in normal voice at } 1 \text { metre. }\end{array}$ \\
\hline $\begin{array}{l}2 \\
\text { Moderate } \\
\text { impairment }\end{array}$ & $\begin{array}{l}41-60 \\
\text { (better ear) }\end{array}$ & $\begin{array}{l}\text { Able to hear and repeat words } \\
\text { spoken in raised voice at } 1 \text { metre. }\end{array}$ \\
\hline $\begin{array}{l}3 \text { - Severe } \\
\text { impairment }\end{array}$ & $\begin{array}{l}\text { 61-80 } \\
\text { (better ear) }\end{array}$ & $\begin{array}{l}\text { Able to hear some words when } \\
\text { shouted into better ear. }\end{array}$ \\
\hline $\begin{array}{l}4 \\
\text { Profound } \\
\text { impairment } \\
\text { including } \\
\text { deafness }\end{array}$ & $\begin{array}{l}81 \text { dB or greater } \\
\text { (better ear) }\end{array}$ & $\begin{array}{l}\text { Unable to hear and understand } \\
\text { even a shouted voice. }\end{array}$ \\
\hline
\end{tabular}

\section{Statistical analysis}

To compare data, Student's t-test was applied. The level $P<0.05$ was considered as the cutoff value or significance.For qualitative parameter (i.e, sex), Fisher Exact test was done. The statistical analysis was done with Graph Pad Quick Calc software, California, USA. Wave Threshold was compared and the test of significance used was Mann Whitney U test. Software used was Vassar Stats: Website for Statistical Computation (vassarstats.net).

\section{Result}

Sex and age wise the 60 children with Receptive Language Disorder were similar with 30 apparently healthy children, taken as control.

\section{I) Assessment of Receptive Language Disorder}

Maximum number of 55 cases $(91.67 \%)$ presented with Receptive Language disorder, while 5 cases $(8.33 \%)$ had no language disorder. 
II) Latency (I,III, V) and Inter Peak Latency (IIII, III-V, I-V)

\section{Right Ear}

In 52(86.67\%) cases, wave $\mathrm{V}$ was present at $70 \mathrm{~dB}$ for Right ear, while in $8(13.33 \%)$ cases Wave V was absent.

Table 2 - Mean Wave latencies of Cases and Controls of Right ear with p-value

\begin{tabular}{|l|c|c|c|}
\hline $\begin{array}{l}\text { BAEP } \\
\text { parameters } \\
\text { Latency in msec }\end{array}$ & $\begin{array}{c}\text { Cases (n=52)\# } \\
\text { Mean ( SD) }\end{array}$ & $\begin{array}{c}\text { Control } \\
(\mathbf{n = 3 0 )} \\
\text { Mean }(\text { SD) }\end{array}$ & P values \\
\hline Wave I & $1.934(0.38)$ & $1.697(0.301)$ & $\mathbf{0 . 0 0 3 7} *$ \\
\hline Wave III & $4.216(0.351)$ & $4.132(0.438)$ & 0.3279 \\
\hline Wave V & $6.868(0.25)$ & $5.918(0.536)$ & $<\mathbf{0 . 0 0 0 1} *$ \\
\hline Wave I-III & $2.26(0.45)$ & $2.123(0.386)$ & 0.1577 \\
\hline Wave III-V & $2.803(0.529)$ & $1.875(0.169)$ & $<\mathbf{0 . 0 0 0 1} *$ \\
\hline Wave I-V & $5.218(0.394)$ & $4.059(0.677)$ & $<\mathbf{0 . 0 0 0 1} *$ \\
\hline
\end{tabular}

* Statistically significant\# Cases where Wave V was present at $70 \mathrm{~dB}$ were taken into consideration.

There was Statistically Significant prolongation of Wave I, Wave V and Wave III-V, Wave I-V inter peak latency at $70 \mathrm{~dB}$ compared to control.

For Different Groups According to Receptive Language Disorder by Early Language Milestone Scale-2 (ELM Scale-2)

\section{1) Children without Receptive Language Disorder according to ELM Scale-2}

In all the $5(100 \%)$ children without Receptive Language Disorder, wave V was present at $70 \mathrm{~dB}$ for Right ear.

Table 3-Mean Wave latencies of Cases and Controls of Right ear with p-value

\begin{tabular}{|l|c|c|c|}
\hline $\begin{array}{l}\text { BAEP } \\
\text { parameters } \\
\text { Latency in msec }\end{array}$ & $\begin{array}{l}\text { Cases (n=5)\# } \\
\text { Mean ( SD) }\end{array}$ & $\begin{array}{l}\text { Control (n=30) } \\
\text { Mean ( SD) }\end{array}$ & P values \\
\hline Wave I & $1.502(0.305)$ & $1.697(0.301)$ & 0.1897 \\
\hline Wave III & $4.354(0.07)$ & $4.132(0.438)$ & 0.272 \\
\hline Wave V & $6.4(0.197)$ & $5.918(0.536)$ & 0.0576 \\
\hline Wave I-III & $2.422(0.584)$ & $2.123(0.386)$ & 0.1454 \\
\hline Wave III-V & $2.024(0.129)$ & $1.875(0.169)$ & 0.0714 \\
\hline Wave I-V & $4.554(0.531)$ & $4.059(0.677)$ & 0.1306 \\
\hline
\end{tabular}

There was no Statistically Significant prolongation of wave latency of Cases at $70 \mathrm{~dB}$ compared to the control.

\section{2) Children with Receptive Language Disorder according to ELM Scale-2}

In 47(85.45\%) children with Receptive Language Disorder, wave V was present at $70 \mathrm{~dB}$ for Right ear, while in $8(14.55 \%)$ cases Wave V was absent.

Table 4 -Mean Wave latencies of Cases and Controls of Right ear with p-value

\begin{tabular}{|c|c|c|c|}
\hline $\begin{array}{l}\text { BAEP } \\
\text { parameters } \\
\text { Latency in msec }\end{array}$ & $\begin{array}{c}\text { Cases }(n=47) \# \\
\text { Mean } \pm \text { SD }\end{array}$ & $\begin{array}{c}\begin{array}{c}\text { Control } \\
(n=30)\end{array} \\
\text { Mean } \pm \text { SD } \\
\end{array}$ & $P$ values \\
\hline Wave I & $1.973(0.364)$ & $1.697(0.301)$ & $0.0009 *$ \\
\hline Wave III & $4.204(0.364)$ & $4.132(0.438)$ & 0.437 \\
\hline Wave V & $6.918(0.199)$ & $5.918(0.536)$ & $<0.0001 *$ \\
\hline Wave I-III & $2.245(0.44)$ & $2.123(0.386)$ & 0.2177 \\
\hline Wave III-V & $2.886(0.486)$ & $1.875(0.169)$ & $<0.0001 *$ \\
\hline Wave I-V & $5.288(0.307)$ & $4.059(0.677)$ & $<0.0001 *$ \\
\hline
\end{tabular}

There was Statistically Significant prolongation of Wave I, Wave V and Wave III-V, Wave I-V inter peak latency at $70 \mathrm{~dB}$ compared to control.

Table 5 -Comparison of Mean Wave latencies of Right ear of Children with Receptive Language Disorder and Children without Receptive Language Disorder with p-value

\begin{tabular}{|c|c|c|c|}
\hline $\begin{array}{l}\text { BAEP } \\
\text { parameters } \\
\text { Latency in } \\
\text { msec }\end{array}$ & $\begin{array}{l}\text { Children with } \\
\text { Receptive } \\
\text { Language } \\
\text { Disorder } \\
\text { (n=47)\# } \\
\text { Mean ( SD) }\end{array}$ & $\begin{array}{c}\text { Children } \\
\text { without } \\
\text { Receptive } \\
\text { Language } \\
\text { Disorder } \\
\text { (n=5)\# } \\
\text { Mean ( SD) } \\
\end{array}$ & P values \\
\hline Wave I & $1.973(0.364)$ & $1.502(0.305)$ & 0.0076* \\
\hline Wave III & $4.204(0.364)$ & $4.354(0.07)$ & 0.3662 \\
\hline Wave V & $6.918(0.199)$ & $6.4(0.197)$ & $\mathbf{0 . 0 0 3}^{*}$ \\
\hline Wave I-III & $2.245(0.44)$ & $2.422(0.584)$ & 0.4103 \\
\hline Wave III-V & $2.886(0.486)$ & $2.024(0.129)$ & $0.0003 *$ \\
\hline Wave I-V & $5.288(0.307)$ & $4.554(0.531)$ & $<0.0001 *$ \\
\hline
\end{tabular}

There was statistically significant correlation between Wave I, Wave V latency and Wave III-V, $\mathrm{I}-\mathrm{V}$ interpeak Latencies of Right ear of Children with Receptive Language Disorder and Children without Receptive Language Disorder according to ELM Scale-2.

\section{Left Ear}

In 54(90\%) cases, wave $\mathrm{V}$ was present at $70 \mathrm{~dB}$ for left ear, while in $6(10 \%)$ cases Wave V was absent. 
Table 6- Mean Wave latencies of Cases and Controls of Left ear with p-value

\begin{tabular}{|c|c|c|c|}
\hline $\begin{array}{l}\text { BAEP } \\
\text { parameters } \\
\text { Latency in } \\
\text { msec }\end{array}$ & $\begin{array}{c}\text { Cases }(n=54) \# \\
\text { Mean } \pm \text { SD }\end{array}$ & $\begin{array}{c}\text { Control }(n=30) \\
\text { Mean } \pm \text { SD }\end{array}$ & $P$ values \\
\hline Wave I & $2.201(0.391)$ & $1.672(0.263)$ & $<0.0001 *$ \\
\hline Wave III & $4.239(0.373)$ & $4.196(0.101)$ & 0.5386 \\
\hline Wave V & $6.38(0.396)$ & $6.021(0.324)$ & $<0.0001 *$ \\
\hline Wave I-III & $2.405(0.575)$ & $2.258(0.286)$ & 0.1937 \\
\hline Wave III-V & $2.544(0.488)$ & $1.56(0.435)$ & $<0.0001 *$ \\
\hline Wave I-V & $4.541(0.466)$ & $4.037(0.622)$ & $<0.0001 *$ \\
\hline
\end{tabular}

There was Statistically Significant prolongation of Wave I, Wave V and Wave III-V, Wave I-V inter peak latency at $70 \mathrm{~dB}$ compared to control.

For Different Groups According to Receptive Language Disorder by Early Language Milestone Scale-2 (ELM Scale-2)

1) Children without Receptive Language Disorder according to ELM Scale-2

In all the $5(100 \%)$ children without Receptive Language Disorder, wave V was present at $70 \mathrm{~dB}$ for Left ear.

Table 7 Mean Wave latencies of Cases and Controls of Left ear with p-value

\begin{tabular}{|l|c|c|c|}
\hline $\begin{array}{l}\text { BAEP } \\
\text { parameters } \\
\begin{array}{l}\text { Latency in } \\
\text { msec }\end{array}\end{array}$ & $\begin{array}{c}\text { Cases }(\mathbf{n}=5) \text { \# } \\
\text { Mean } \mathbf{\text { SD }}\end{array}$ & $\begin{array}{c}\text { Control }(\mathbf{n}=\mathbf{3 0}) \\
\text { Mean } \mathbf{\text { SD }}\end{array}$ & P values \\
\hline Wave I & $1.84(0.42)$ & $1.672(0.263)$ & 0.2336 \\
\hline Wave III & $4.186(0.272)$ & $4.196(0.101)$ & 0.8781 \\
\hline Wave V & $5.876(0.293)$ & $6.021(0.324)$ & 0.3556 \\
\hline Wave I-III & $2.154(0.221)$ & $2.258(0.286)$ & 0.4471 \\
\hline Wave III-V & $1.906(0.051)$ & $1.56(0.435)$ & 0.0886 \\
\hline Wave I-V & $4.016(0.165)$ & $4.037(0.622)$ & 0.9413 \\
\hline
\end{tabular}

There was no Statistically Significant prolongation of wave latency of Cases at $70 \mathrm{~dB}$ compared to the control.

\section{2) Children with Receptive Language Disorder according to ELM Scale-2}

In 49(89.09\%) children with Receptive Language Disorder, wave $\mathrm{V}$ was present at $70 \mathrm{~dB}$ for Left ear, while in $6(10.91 \%)$ cases Wave V was absent.
Table 8 -Mean Wave latencies of Cases and Controls of Left ear with p-value

\begin{tabular}{|c|c|c|c|}
\hline $\begin{array}{l}\text { BAEP } \\
\text { parameters } \\
\text { Latency in } \\
\text { msec }\end{array}$ & $\begin{array}{c}\text { Cases }(n=49) \# \\
\text { Mean } \pm \text { SD }\end{array}$ & $\begin{array}{c}\begin{array}{c}\text { Control } \\
(n=30)\end{array} \\
\text { Mean } \pm \text { SD }\end{array}$ & $P$ values \\
\hline Wave I & $2.234(0.376)$ & $1.672(0.263)$ & $<0.0001 *$ \\
\hline Wave III & $4.244(0.382)$ & $4.196(0.101)$ & 0.5033 \\
\hline Wave V & $6.432(0.37)$ & $6.021(0.324)$ & $<0.0001 *$ \\
\hline Wave I-III & $2.428(0.592)$ & $2.258(0.286)$ & 0.146 \\
\hline Wave III-V & $2.609(0.465)$ & $1.56(0.435)$ & $<0.0001 *$ \\
\hline Wave I-V & $4.621(0.445)$ & $4.037(0.622)$ & $<0.0001 *$ \\
\hline
\end{tabular}

There was Statistically Significant prolongation of Wave I, Wave V and Wave III-V, Wave I-V inter peak latency at $70 \mathrm{~dB}$ compared to control.

Table 9 Comparison between Mean Wave latencies of Left ear of Children with Receptive Language Disorder and Children without Receptive Language Disorder with p-value

\begin{tabular}{|c|c|c|c|}
\hline $\begin{array}{l}\text { BAEP } \\
\text { parameters } \\
\text { Latency in } \\
\text { msec }\end{array}$ & $\begin{array}{c}\text { Children with } \\
\text { Receptive } \\
\text { Language } \\
\text { Disorder }(n=49) \\
\# \\
\text { Mean } \pm \text { SD } \\
\end{array}$ & $\begin{array}{c}\text { Children } \\
\text { without } \\
\text { Receptive } \\
\text { Language } \\
\text { Disorder(n=5)\# } \\
\text { Mean } \pm \text { SD }\end{array}$ & $P$ values \\
\hline Wave I & $2.234(0.376)$ & $1.84(0.42)$ & 0.0315* \\
\hline Wave III & $4.244(0.382)$ & $4.186(0.272)$ & 0.7429 \\
\hline Wave V & $6.432(0.37)$ & $5.876(0.293)$ & $0.002 *$ \\
\hline Wave I-III & $2.428(0.592)$ & $2.154(0.221)$ & 0.3124 \\
\hline Wave III-V & $2.609(0.465)$ & $1.906(0.051)$ & 0.0015* \\
\hline Wave I-V & $4.621(0.445)$ & $4.016(0.165)$ & $0.0042 *$ \\
\hline
\end{tabular}
at $70 \mathrm{~dB}$ were taken into consideration.

There was statistically significant correlation between Wave I, Wave V latency and Wave III-V, I-V interpeak Latencies of Left ear of Children with Receptive Language and Children without Receptive Language Disorder according to ELM Scale-2. 
III) Threshold (in dB) in all Cases

\section{A) Right Ear}

Table 10 showing number of cases in each threshold group according to Grading of Hearing Sensitivity (WHO)

In Right Ear of Cases based on evaluation by Early Language Milestone Scale 2

\begin{tabular}{|l|l|l|}
\hline $\begin{array}{l}\text { Early Language } \\
\text { Milestone Scale 2 } \\
\text { evaluation }\end{array}$ & $\begin{array}{l}\text { No. of } \\
\text { Cases } \\
(\mathbf{n = 6 0})\end{array}$ & $\begin{array}{l}\text { Grading of Hearing Sensitivity } \\
\text { (WHO) }\end{array}$ \\
\hline $\begin{array}{l}\text { No Receptive } \\
\text { Language } \\
\text { Disorder }\end{array}$ & 5 & $\begin{array}{l}\text { Normal hearing sensitivity }(<\mathbf{2 5} \\
\mathbf{d B})\end{array}$ \\
\hline $\begin{array}{l}\text { Receptive } \\
\text { Language } \\
\text { Disorder }\end{array}$ & 2 & $\begin{array}{l}\text { Normal hearing sensitivity }(<\mathbf{2 5} \\
\mathbf{d B})\end{array}$ \\
\cline { 2 - 4 } & 18 & $\begin{array}{l}\text { Mild hearing impairment (26dB- } \\
\mathbf{4 0 d B})\end{array}$ \\
\cline { 2 - 4 } & 24 & $\begin{array}{l}\text { Moderate hearing impairment } \\
(\mathbf{4 1 d B}-60 d B)\end{array}$ \\
\cline { 2 - 4 } & 3 & $\begin{array}{l}\text { Severe hearing impairment } \\
(\mathbf{6 1 d B}-80 d B)\end{array}$ \\
\cline { 2 - 4 } & 8 & $\begin{array}{l}\text { Profound hearing impairment } \\
(\mathbf{8 1 d B})\end{array}$ \\
\hline
\end{tabular}

Most (50\%) cases had Moderate hearing impairment in the Right ear

\section{B) Left Ear}

Table 11 showing number of cases in each threshold group according to Grading of Hearing Sensitivity (WHO)

In Left Ear of Cases based on evaluation by Early Language Milestone Scale 2

\begin{tabular}{|c|c|c|}
\hline $\begin{array}{l}\text { Early Language Milestone } \\
\text { Scale } 2 \text { evaluation }\end{array}$ & $\begin{array}{l}\text { No. of } \\
\text { Cases } \\
(\mathbf{n}=60)\end{array}$ & $\begin{array}{l}\text { Grading of Hearing } \\
\text { Sensitivity(WHO) }\end{array}$ \\
\hline $\begin{array}{l}\text { No Receptive Language } \\
\text { Disorder (No delays and a } \\
\text { maximum of } 1 \text { caution) }\end{array}$ & 5 & $\begin{array}{l}\text { Normal hearing } \\
\text { sensitivity }(<\mathbf{2 5} \mathbf{~ d B})\end{array}$ \\
\hline \multirow{5}{*}{$\begin{array}{l}\text { Receptive } \\
\text { Disorder (two or more } \\
\text { Cautions and /or One or } \\
\text { more Delays) }\end{array}$} & 1 & \\
\hline & 16 & $\begin{array}{ll}\text { Mild } & \text { hearing } \\
\text { impairment } & \text { (26dB- } \\
\text { 40dB) } & \\
\end{array}$ \\
\hline & 32 & $\begin{array}{l}\text { Moderate } \\
\text { impairment } \\
\text { 60dB) } \\
\end{array}$ \\
\hline & 1 & $\begin{array}{l}\text { Severe } \\
\text { impairment } \\
\text { 80dB) }\end{array}$ \\
\hline & 5 & $\begin{array}{l}\text { Profound hearing } \\
\text { impairment }(\geq \mathbf{8 1 d B})\end{array}$ \\
\hline
\end{tabular}

Most (53.33\%) cases had Moderate hearing impairment in the Left ear.

The mean threshold was calculated by Mann Whitney U test and the P-values analysed. There was statistically significant increase of threshold of both ears of cases compared to controls.

\section{Discussion}

Basic communication skills are developed by the time a child enters kindergarten. Children with receptive language disorders often have difficulty organizing their thoughts while trying to understand others, which creates problems in communicating. In Many of the cases, the underlying cause of Receptive Language Disorder is hearing loss. ${ }^{[4]}$ Children with hearing loss may have difficulty with understanding sounds around them.

Brainstem evoked response audiometry (BERA) has been well documented as a method of screening deafness in the very young child. There is evidence suggesting a connection between language impairments and a central auditory processing disorder ${ }^{[12]}$ Further, BAER is not significantly altered by the state of consciousness, drugs and a variety of environmental factors. ${ }^{[13]}$ So, BERA can be used as a tool for assessment of auditory dysfunction in high risk children.

This cross sectional and observational study was carried out with 60 children with receptive language disorder and 30 age and sex matched control. All the children belonged to the age group of 1-3 years. They were subjected to BERA testing following standard procedures and the BAEP findings of the cases were analysed with respect to the controls. The parameters studied were the latencies of Wave I, III, V, I-V,III-V, and I-III interpeak latency and wave $\mathrm{V}$ threshold of each ear. The present study used Early Language Milestone Scale $2^{[9]}$ as a tool to assess the Receptive Language Disorder of the children. It is a simple tool that can be used to assess language development in children who are younger than three years of age.

Out of the 60 children, $56(93.33 \%)$ children showed some abnormality of latency and/ or threshold in one or both ears. The major abnormalities were absence of wave $\mathrm{V}$ or increase in wave $\mathrm{V}$ latency at $70 \mathrm{~dB}$. Wave $\mathrm{V}$ at $70 \mathrm{~dB}$ was absent in 3(10\%) cases in both ears.

For both right and left ears of the cases where Wave $\mathrm{V}$ was present at $70 \mathrm{~dB}$, there was 
statistically significant prolongation of Wave I, Wave $\mathrm{V}$ and Wave III -V, Wave I-V inter peak latency compared to controls.

This indicates a prolongation of both Peripheral and Central Auditory transmission time.

The findings of this study were similar to findings by Mishra P.K. et al. ${ }^{[14]}$ who showed transient prolongation of latencies of various waves including wave I, wave V latencies.

On the other hand, In study by Roncagliolo $\mathrm{M}$, et $\mathrm{al}^{[15]}$, there were no significant differences in central conduction time of auditory pathway (I- V interval) of children with language disorders aged 4-9 years.

In study conducted by Akshoomoff $\mathrm{N}^{[16]}$ et al BAEPs for the receptive developmental language disorder were comparable to the control group.

In the present study, the following findings were statistically significant.

Of the 60 cases, 55(91.67\%) of the children presented with Receptive Language Disorder according to Early Language Milestone Scale 2.

Latency of wave I, V and Wave III-V, Wave I-V IPL was delayed. Delayed wave I latency suggested abnormality in peripheral auditory pathway transmission time (PTT). Delayed Wave $\mathrm{V}$, Wave III-V and I-V inter peak latency suggested an abnormality of Central auditory transmission time. This shows that children with delayed speech are at a risk of impaired auditory transmission which can be a combination of both Central and Peripheral abnormality.

This was the first study in eastern India corelating ELM Scale-2 score evaluating speech and language impairment with BAEP parameters. The children who had Receptive Language Disorder according to ELM Scale-2had statistically significant prolongation of Wave I and V latency \& III-V and I-V interpeak Latency of both Right and Left ear at $70 \mathrm{~dB}$ compared to control.

It was also found that the children who did not have Receptive Language Disorder according to ELM Scale-2had no statistically significant wave latency at $70 \mathrm{~dB}$ of both Right and Left ear compared to control. This indicates that the findings of ELM Scale 2 corresponded with the findings of BAEP waves.

There was elevation of threshold of hearing with various degrees of sensorineural hearing loss and was likely a combination of both peripheral and central transmission abnormality. The children with Receptive Language Disorder had increased hearing threshold.

An attempt was made in this study to analyse the different effect of Receptive Language Disorder on BAEP in different age groups. Many previous studies mention about raised threshold in children with language disorder, especially with hearing loss. This study categorizes the degrees of hearing loss based on the raised threshold. There were some limitations of this present study. This was a cross-sectional study, though follow up study is better to observe the effect of Speech therapy. Also, a large Sample size would be useful to have adequate children to divide in multiple age groups to Early Language Milestone Scale 2.

\section{Conclusion}

This study has demonstrated that significant BAEP changes occur in children with Receptive Language Disorder with varying degree of hearing loss. Both ears had BAEP changes indicating abnormality of both Central And peripheral auditory transmission. Most children had Moderate hearing loss.

Children with Receptive Language Disorder according to Early Language Milestone Scale 2 score had both Central and Peripheral Auditory Transmission delay as found by BAEP. Results of this study underline the importance of auditory evoked potentials in evaluating children's auditory System. Diagnosing the auditory damage and hearing loss early can helpin formulating treatment and rehabilitation plan.

Sources of support- Self Sponsored

\section{References}

1. Law J, Boyle J, Harris F, Harkness A, Nye C. Prevalence and natural history of 
primary speech and language delay: findings from a systematic review of the literature. Int J Lang Commun Disord. 2000 Apr-Jun;35(2):165-88.

2. Mondal N, Bhat B, Plakkal N, Thulasingam M, Ajayan P, et al. Prevalence and Risk Factors of Speech and Language Delay in Children Less Than Three Years of Age, J Compr Ped. 2016 ; 7(2):e33173

3. Shetty P. Speech and language delay in children: A review and the role of a pediatric dentist. J Indian Soc Pedod Prev Dent. 2012;30:103

4. Keilmann A, Kluesener P, Freude C, Schramm B. Manifestation of speech and language disorders in children with hearing impairment compared with children with specific language disorders, Logopedics Phoniatrics Vocology, 2011, 36:1, 12-20

5. Dublin WB. Neurological lesion of erythroblastosis fetalis in relation to nuclear deafness. Am J Clin Pathol 1951; 21: 935939.

6. Thornton ARD. Stimulus, recording and subject factor influencing ABR diagnostic criteria. Br J Audiol. 1987; 21:183-189.

7. Savic L, Milosevic D, Komazec Z. Diagnosis of hearing disorders in children with early evoked auditory brainstem potentials. Med Pregl. 1999; 52(3-5):14650.

8. Moore RM, Pinel T, Zhao JH, March R, Jawaid A. Selecting cases from nuclear families for case-control association analysis. BMCGenetics. 2005; 6 suppl 1:S105.

9. Coplan J. ELM scale: the early language milestone scale. Austin, Tex.: Pro-Ed, 1987.

10. Aminoff M.J. Electrodiagnosis in clinical neurology,4th edition, Part II, Churchill Livingstone;451-491.

11. World health organization. Newborn And Infant hearing screening. Grades of hearing impairment. Accessed August 282017. http://www.who.int/pbd/deafness/ hearing_impairment_grades/en/.

12. Deorari AK, Garg R, Bisht MS, Ahuja GK, Paul VK, Singh M. Auditory brainstem evoked response in normal neonates and infants. Indian Pediatr 1989, 26: 981-986.

13. Stockard JJ, Stockard JE, Sharbrough FW. Nonpathologic factors influencing brainstem history evoked potential. Am J EEG Technol. 1978; 18:177.

14. Mishra PK et al. Brainstem auditory evoked responses in neonates with birth asphyxia, Indian journal ofpediatrics 1997, 34:199-205.

15. Roncagliolo M, Benítez J, Pérez $M$. Auditory brainstem responses of children with developmental language disorders. Dev Med Child Neurol. 1994;36:26-33

16. Akshoomoff N, Courchesne E, YeungCourchesne R, Costello J. Brainstem auditory evoked potentials in receptive developmental language disorder. Brain Lang. 1989 Oct;37(3):409-18. 